\title{
Metallurgical Use of Heat Altered Coal: A Case Study
}

\author{
Debjani Nag*, A.K. Singh and P.K. Banerjee
}

R\&D Division, Tata Steel Limited, Jamshedpur-831001, India

*Corresponding Author: debjani.nag@tatasteel.com,Tel+916572148938

\begin{abstract}
The effects of igneous intrusion on coal are observed in various parts of the world. It is found that igneous intrusions have altered the quality and characteristics, especially the coke ability of the coals. It has been estimated that a large quantity of heat affected (jhama) coal is reserved in the Jharia collieries of India. Nowadays, apart from difficulties of mining, its utilization is the biggest issue. This paper presents a brief overview of heat altered coal and also highlights some studies, undertaken in Tata Steel to make best possible metallurgical use of jhama especially in steel industry.
\end{abstract}

Key Words: Jhama; igneous intrusion; thermally altered; natural coke.

\section{INTRODUCTION}

Coal affected by igneous intrusion is a common phenomenon. Thermally affected coals are known by various names such as Natural Coke, Geological Coke, Burnt Coke, Cinder and Jhama. The kind of coal alteration depends on the temperature of the intrusion, the duration of magmatic heating and the distance of coal from direct contact with the igneous rock. The thermal influence depends on the thickness, nature and form of the intrusive body as well as on the composition and rank of the intruded organic-rich rock [1]. In general, igneous intrusions cause dramatic changes in vitrinite reflectance, mineralogy and geochemistry of the coal seams. In most cases, these changes are gradual with distinct physical and optical properties [2-4].

Three zones in the intrusion affected coal seams can be demarcated as (i) normal coal (\%Romax 0.8-1.2\%) (ii) slightly thermally altered coal (\%Romax 1.2-1.8\%) and (iii) highly thermally altered coal (\%Romax 1.8-5.0\%) [5]. Several authors have studied the different properties of thermally altered coal. The impact of igneous intrusions on the organic component of coal has been reported in the U.S.A [6-8]; U.K [9], Australia [10-14], Antarctica [15], China [16, 17], India [18], Poland [19] and Turkey [20]. It has been found that volatile matter and total hydrogen decrease towards the contact zone, while ash, total carbon and vitrinite reflectance all 
steadily increase. The volatile matter and ultimate analysis characteristics of the highly affected coals indicate that it is more like semi-coke, rather than a completely carbonized product. Finkelman, et al. [21], Goodarzi and Cameron [22], Merritt [23], Querol, et al. [24, 25] and Alexandra and Paul [26] studied the effect of igneous intrusions on the inorganic constituents of coal. According to Finkelman et al [21], there are three ways by which the intrusion could modify the inorganic element composition of a coal: (i) removal of elements by volatilization, (ii) residual concentration of elements in refractory phases and (ii) addition or removal of elements by fluids directly derived from the intrusion or from a hydrothermal system generated at the intrusion-host boundary. According to Alexandra and Paul [26], majority of elements in the altered coal have affinities to aluminosilicate minerals. Ankerite and siderite are products of thermal alteration and only occur in the altered coal and dykes.

The microstructure of thermally affected coal has been investigated by several workers like Singh, et al. [3], Kwiecinska and Petersen [1], Singh, et al.[2], Suchy, et al. [27], Bourrat, et al. [28], Goodarzi and Murchison [29]. The optical changes of the coal induced by the thermal metamorphism depend on the initial rank of the coal and its level of maturity at the time of intrusion. In natural coke formed from bituminous coals, three groups of micro constituents may be recognized: (i) matrix (groundmass) formed by total alteration of vitrinite and liptinite; (ii) macerals of the inertinite group with preserved structures and textures visible in the unaltered coal; (iii) new components, which are partly high-carbon material and partly mineral matter, formed due to the intrusion. Entirely coked vitrinite, especially from bituminous coals, often exhibits mosaic structure (fine, medium, coarse) showing variable degree of optical anisotropy. The anisotropy and reflectance increase with the temperature of alteration. The occurrence of mosaic structure is one of the primary features which distinguish natural coke from natural char. All these findings discussed above are unique to coal samples because there are number of factors that may cause differences in the chemical nature of thermally altered coal. In this paper an attempt has been taken to give a brief description about the jhama coal of Jharia coalfields of India.

\section{ORIGIN AND MINING OF JHAMA}

In India, a large amount of thermally metamorphosed coal has been found in the Damodar Valley coalfields of Jharia, which is a part of Lower Gondwana coalfields. Here these coals are known as jhama. In the Indian coal scenario Jharia coalfield occupies a special status as this is the only storehouse of prime coking coal and has been meeting the coking coal needs of the country for over a century. Coal mining in the coalfield was started in the last decade of the 19th century. It is a sickle shaped coalfield occurring in the form of a basin truncated with a major boundary fault on the southern flank. The arcuate coalfield, measuring about $40 \mathrm{~km}$. in length and $12 \mathrm{~km}$. in width, occupies an area of nearly $450 \mathrm{sq}$. $\mathrm{km}$.

Uncontrolled coal fires reportedly began in the Jharia coalfield in 1916, about 26 years after the start of mining [30]. The origin of most coal- mine- fires in India is reported to be the result of spontaneous combustion. Although the coals of the Jharia Coal Field are not as susceptible to spontaneous combustion as some other coals in India [31], irresponsible mining practice prior to 
nationalization resulted in enhancing self heating of the coal. Large volumes of fragmented coal in thick seams, crushed pillars, poor ventilation and surface subsidence fractures resulted in conditions ideal for spontaneous combustion to occur. A study conducted by the Central Mine Planning and Design Institute Limited (CMPDIL) of nearly one hundred fire sites in India resulted in identifying spontaneous heating as the cause of about 67 percent of the fires. About 33 percent were attributable to some form of neglect, accident or design [32].

In Jharia, major part of the reserve of coking coal is altered due to igneous intrusion (Figure 1). For example, the total insitu reserve of jhama at Jharia Division of Tata Steel is 154.10 million tonne wherein the extractable reserve is only 8.64 million tonne. Due to metamorphism, the pseudo carbonization takes place and coking coals are converted in to natural coke or jhama. Problems related to mining of jhama were analyzed by Singh, et al [33]. They suggested that the rating of a coaling machine should be increased for cutting of a coal seam with frequent igneous intrusions. The nature and extent of influence of the igneous intrusions seem to be quite complex and it has substantially altered the physico-chemical properties of the surrounding coal mass. Here, the igneous intrusions causing regional in situ burning of a coal seam are normally micaperidotite and dolerite. After tearing the coal seam along the lower resistance path, the intruded igneous materials appear in the form of a dyke and a sill in and around a coal seam. Thermocontact transformation, as a result of the igneous intrusion, resulted in a significant change in physico-mechanical properties of a coal seam. A hypothetical schematic diagram showing the effect of intrusions on coal seams has been presented in Figure 2.

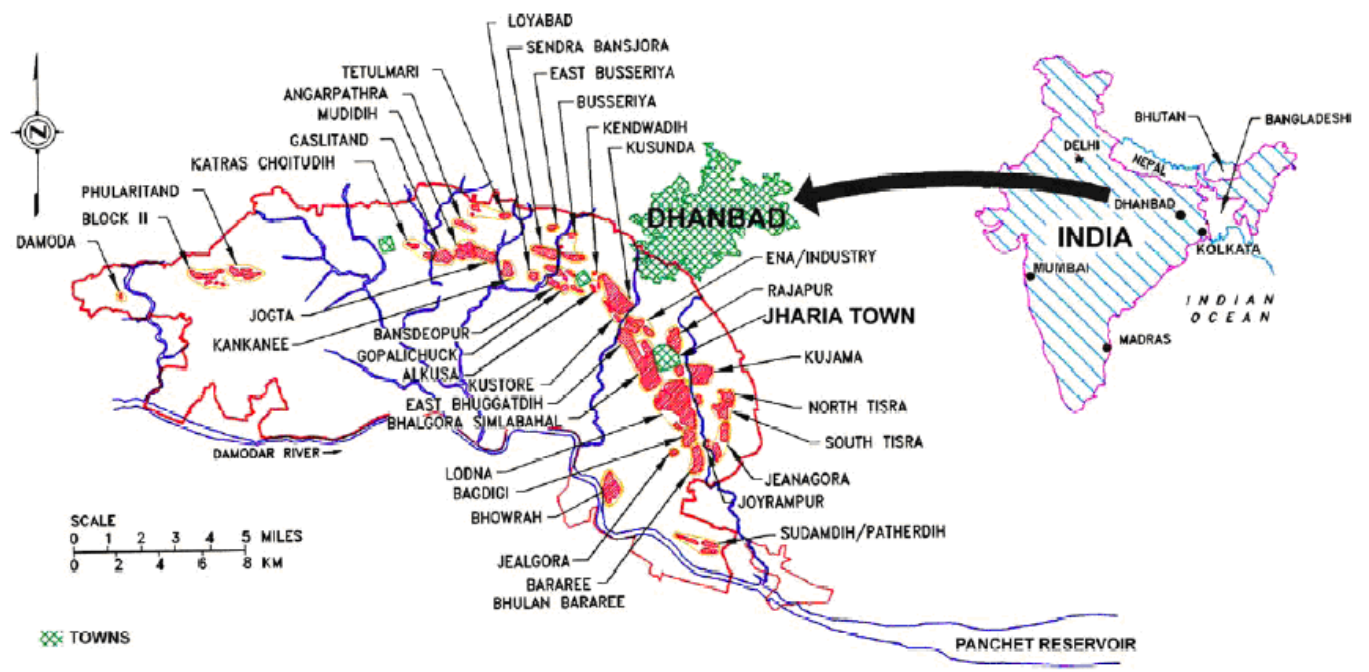

Fig. 1. Heat affected coals in Jharia (Singh, et al., 2008). 


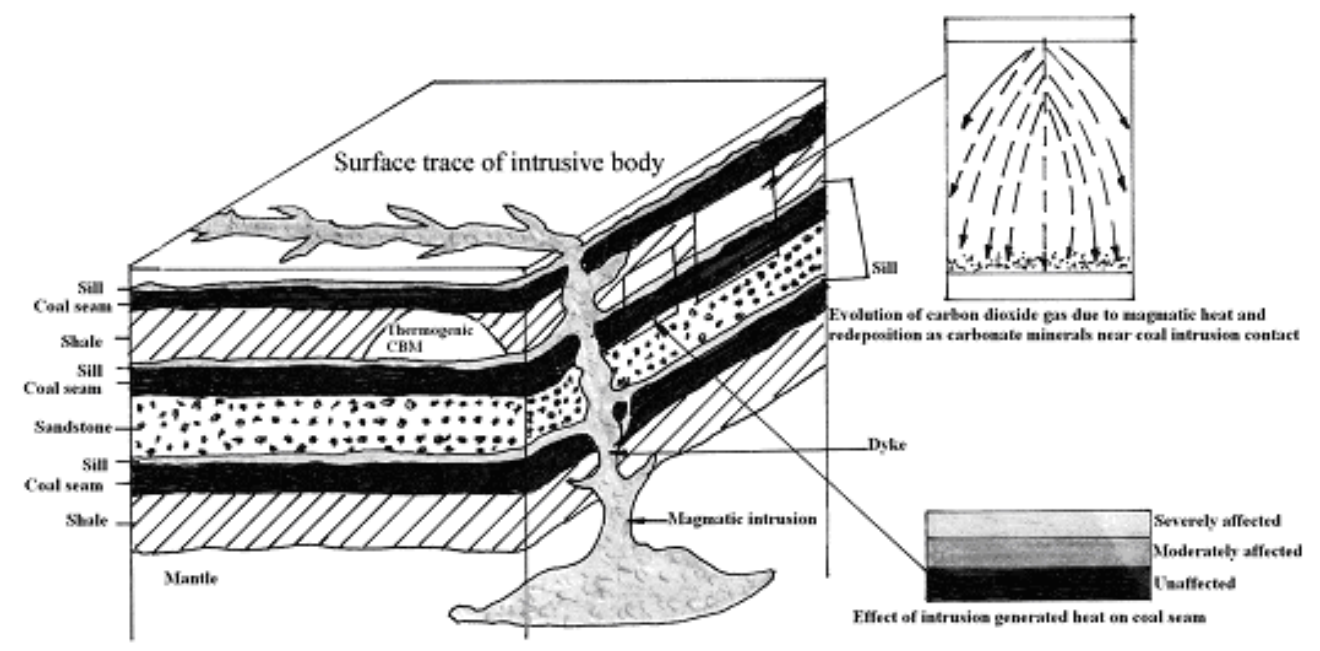

Fig 2. Schematic presentation of magmatic intrusion affecting the coal seam in Jharia Coalfield, Damodar Valley India (Singh, et al., 2008).

\section{PROPERTIES AND UTILIZATION OF JHAMA}

The presence of jhama causes the estimation of the quality and quantity of coal in any area or seam to be problematic because of the coal's heterogeneous alteration and compact nature. Due to the various difficulties very few systematic characterisation was done earlier. Hence, proper industrial utilisation of heat affected coal could not be made till now. Macroscopical observation revealed that jhama is usually dull, compact and hard. It has vacuoles (pores) which are empty or infilled with mineral matter (Figure 3). The immediate contact between the igneous intrusive body and the coal may be sharp and planar or it may be diffuse and irregular. The optical changes of the coal induced by the thermal metamorphism depend on the initial rank of the coal and the level of maturity of the coal at the time of intrusion. In jhama three groups of micro constituents may be recognized. They are matrix (groundmass) formed by total alteration of vitrinite and liptinite, macerals of the inertinite group with preserved structures and textures visible in the unaltered coal and new components, which are partly high-carbon material and partly mineral matter, formed due to the intrusion [1]. Figure 4 presents some micrographs of jhama coal taken from Jharia coal field.

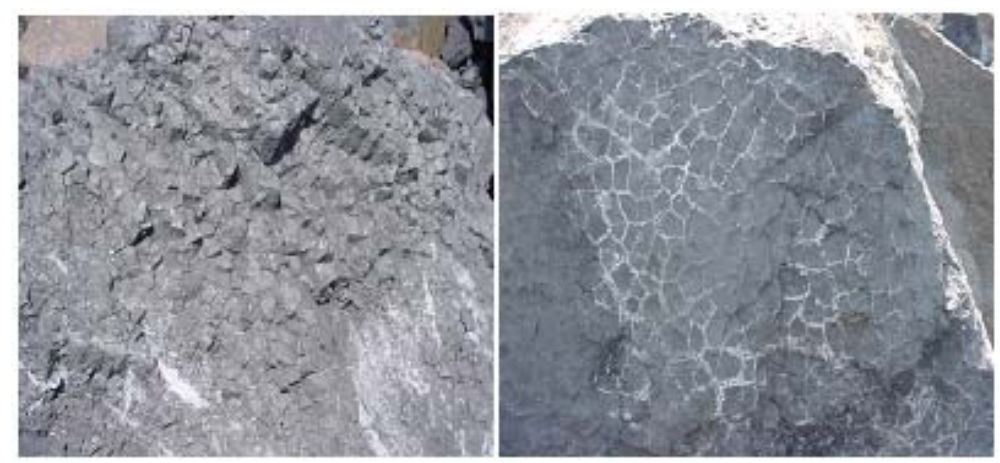

Fig. 3. Field photograph of jhama coal. 


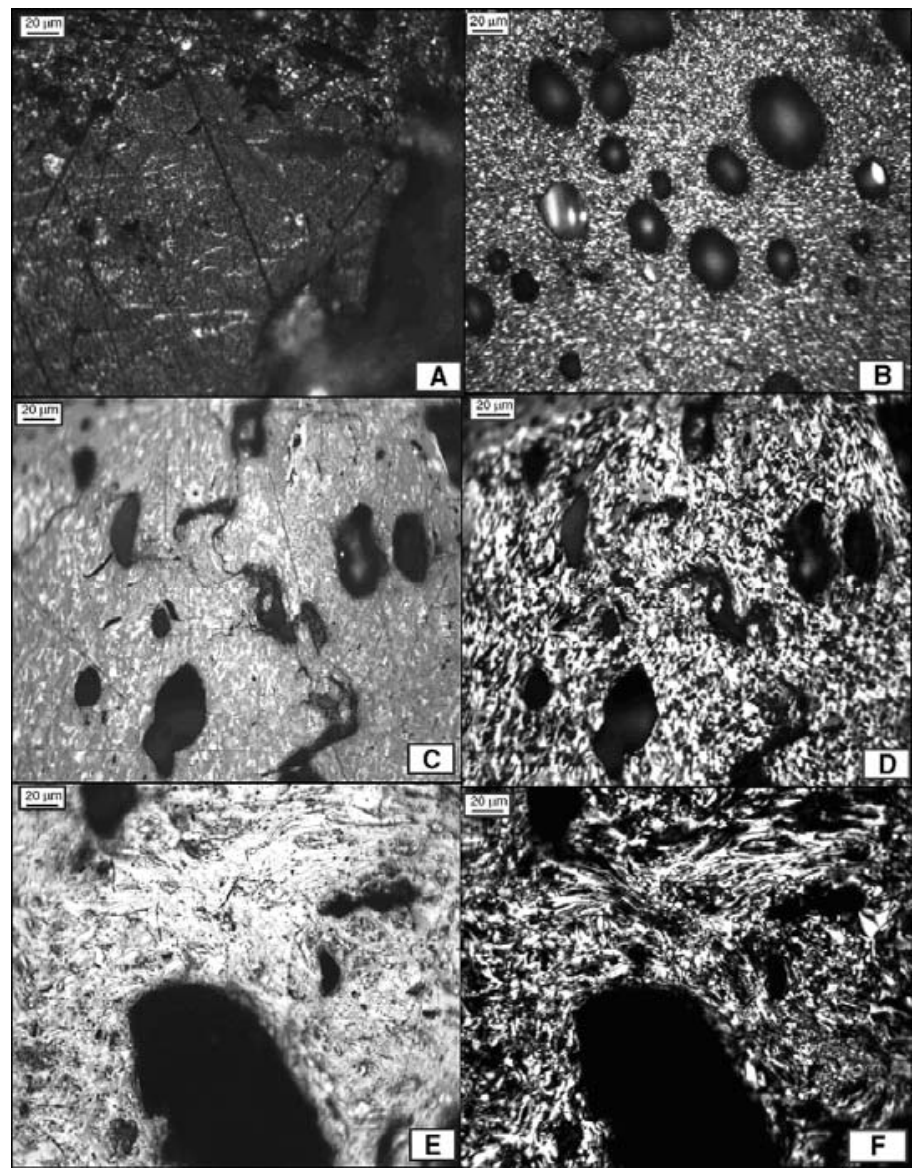

Fig 4. (A) Vitrinite maceral altering into mesophase sphere and mosaics; (B) Mesophase spheres, mosaics and devolatilzation pores; (C) Natural coke groundmass with devolatilization pores and cracks; (D) Same field showing mesophase spheres mosaics and fine flow structure (E) Natural coke groundmass showing flow structure and vesicles; (F) Flow structures and mosaics of different sizes with prominent anisotropy, fine flow structure and mineral matter under crossed (Singh, et al., 2007).

Some preliminary studies have been made by Tata Steel Limited in the past. Some initiative has taken for the washability study of jhama. This study has been done in CFRI, Dhanbad. Detailed washability studies followed by laboratory flotation revealed that theoretical yield of $25.3 \%$ at $13 \%$ ash level are achievable when the raw jhama is crushed to $75 \mathrm{~mm}$. While, for the raw jhama crushed to $10 \mathrm{~mm}$ the theoretical yield improved to $442 \%$ at an ash level of $13.2 \%$. In order to use jhama as one of component in coal blend for coke making, it was characterised by some preliminary tests like proximate analysis, ultimate analysis, fluidity, dilation, HGI, calorific value, crucible swelling number and petrographic studies. Some of the properties of slightly affected jhama are listed in Table 1 (a, b, c). It is characterized by high ash, low volatile matter and high fixed carbon. Results indicate that jhama has significant amount of reactive material 
(reflectance of desired level) (Table 1c) and it can also fulfill the requirement of reactives in coal blend. It was found that the jhama collected from different seam have difference in their properties. So the sample should be properly characterized before any application.

Table 1: Properties of jhama coal.

\begin{tabular}{|l|l|l|l|l|l|l|l|l|}
\hline \multicolumn{3}{|c|}{ Proximate Analysis (\%) } & \multicolumn{5}{c|}{ Ultimate Analysis (\%) } \\
\hline Ash & $\begin{array}{l}\text { Volatile } \\
\text { Matter }\end{array}$ & Moisture & $\begin{array}{l}\text { Fixed } \\
\text { Carbon }\end{array}$ & Carbon & Hydrogen & Sulphur & Nitrogen & Oxygen \\
\hline 16.83 & 11.70 & 1.93 & 69.54 & 89.90 & 3.28 & 0.44 & 2.25 & 4.13 \\
\hline
\end{tabular}

(a)

\begin{tabular}{|c|c|c|c|c|c|}
\hline \multirow[t]{2}{*}{ Fluidity } & \multicolumn{2}{|c|}{ Dilatometry } & \multirow[t]{2}{*}{ CSN } & \multirow[t]{2}{*}{ HGI } & \multirow{2}{*}{$\begin{array}{l}\text { CV } \\
\mathrm{kcal} / \mathrm{kg}\end{array}$} \\
\hline & $\begin{array}{l}\text { Max } \\
\text { contraction } \\
(\%)\end{array}$ & $\begin{array}{l}\text { Max } \\
\text { expansion } \\
(\%)\end{array}$ & & & \\
\hline Nil & 3 & Nil & 1 & 84.0 & 6414 \\
\hline
\end{tabular}

(b)

\begin{tabular}{|l|l|l|l|l|l|}
\hline Vitrinite & Semi Vitrinite & Exinite & Inertinite & Mineral Matter & $\begin{array}{l}\text { Average } \\
\text { Vitrinite } \\
\text { Reflectance (R) }\end{array}$ \\
\hline 26.5 & 2.5 & 1.0 & 63.2 & 6.8 & 1.07 \\
\hline
\end{tabular}

(c)

\section{CONCLUSIONS}

Jhama being partially carbonized is expected to lose all its coking properties and also have difficult washability characteristics due to more uniform distribution of mineral matters in the partially carbonized coal matrix. This makes its large-scale applications, such as, coke making or PCI challenging to us. To achieve this objective, intensive and through research is needed to investigate the detail characteristics (physical, microscopical and chemical) and beneficiation study of jhama and finally to find out a guideline for industrial use. 


\section{ACKNOWLEDGEMENT}

The authors gratefully acknowledge the Management of Tata Steel for granting permission to publish the work.

\section{REFERENCES}

[1] Kwiecinska, B., Petersen, H.I., 2004, “Graphite, Semi-graphite, Natural Coke, and Natural Char Classification-ICCP System.” International Journal of Coal Geology, Vol. 57, pp. 99116.

[2] Singh, A.K., Singh. M.P., Sen, K., 2003, "New Classification Scheme for Microtextures of Natural Cokes: A Case Study from Heat-affected Coking Coals of Jharia Coal Field, India.” Proceedings, $20^{\text {th }}$ International Pittsburgh Coal Conference, Pittsburgh Coal Conference, September 15-19.

[3] Singh, A.K., Singh, M.P., Sharma, M., Srivastava, S.K., 2007, "Microstructures and microtextures of Natural Cokes: A Case Study of Heat-altered Coking Coals from the Jharia Coalfield, India.” International Journal of Coal Geology, Vol. 71, pp. 153-175.

[4] Stukalova, I.E., Rusinova, O.V., 2007, “Thermal Alteration of Coal in the Khasyn Coalfield, Magadan Region, Russia.” International Journal of Coal Geology, Vol. 71, pp. 462-470.

[5] Singh, A.K., Sharma, M., Singh, M.P., 2008, "Genesis of Natural Cokes: Some Indian Examples.” International Journal of Coal Geology, Vol. 75, pp. 40-49.

[6] Podwysocki, M.H., Dutcher, R.R., 1971, “Coal Dykes that Intrude Lamprophyre Sills: Pargatoire River Valley, Colorado.” Economic Geology, Vol. 66, pp. 267-280.

[7] Thorpe, A.N. Senftle, F.E., Finkelman, R.B., Dulong, F.T., Bostick, N.H., 1998, “Change in the Magnetic Properties on Bituminous Coal Intruded by an Igneous Dike.” International Journal of Coal Geology, Vol. 36, pp. 243-258.

[8] Meyers, P.A., Simoneit, B.R.T., 1999, "Effects of Extreme Heating on the Elemental and Isotopic Compositions of an Upper Cretaceous Coal.” Organic Geochemistry, Vol. 30, pp. 299-305.

[9] Murchison, D.G., Raymond, A.C., 1989, "Igneous Activity and Organic Maturation in the Midland Valley of Scotland.” International journal of Coal Geology, Vol. 14, pp. 47-82.

[10] Taylor, G.H., 1961, "Development of Optical Properties of Coke during Carbonization.” Fuel, Vol. 40, pp. 465-471.

[11] Kisch H.J., Taylor, G.H., 1966a, "Metamorphism and Alteration near an Intrusive Contact.” Economic Geology, Vol. 61, pp. 343-361.

[12] Kisch, H.J., 1966b, "Carbonization of Semi-anthracitic Vitrinite by an Analcime Basanite Sill.” Economic Geology, Vol. 61, pp. 1043-1063.

[13] Gurba, L.W., Ward, C.R., 2000, “Elemental Compositions of Coal Macerals in Relation to Vitrinite Refelctance.” International Journal of Coal Geology, Vol.44, pp. 127-144. 
[14] Othman, R., Ward, C.R., 2002, "Thermal Maturation Pattern in the Southern Bowen, Northern Gunnedah and Surat Basins, Northern New South Wales.” International Journal of Coal Geology, Vol. 51, pp. 145-167.

[15] Brown, H.R., Taylor, G.H., 1961, “Some Remarkable Anthracitic Coal.” Fuel, Vol. 40, pp. 211-224.

[16] Zheng, Z., Zhang, J., Huang, J.Y., 1996, “Observations of Microstructure and Reflectivity of Coal Graphites for Two Locations in China.” International Journal of Coal Geology, Vol. 30, pp. 277-284.

[17] Ren, D., Zhao, F., Wang, Y., Yang, S., 1999, “Distributions of Minor and Trace Elements in Chinese Coals.” International Journal of Coal Geology, Vol. 40, pp. 109-118.

[18] Ghosh, T.K., 1970, “Reflectance of Himalayan Coal.” Fuel, Vol. 49, pp. 226-228.

[19] Kwiencinska, B.K., Hamburg, G., Vleeskens, J.M., 1992, "Formation temperature of Natural Coke in the Lower Silesian Coal Basin, Poland. Evidence from Pyrite and Clays by SEM-EDX.” International Journal of Coal Geology, Vol. 21, pp. 217-235.

[20] Ward, C.R., Warbrooke, P.R., Roberts,F.I., 1989, “Geochemical and Mineralogical Changes in a Coal Seam due to Contact Metamorphism., Sydney Basin, New South Wales, Australia.” International Journal of Coal Geology, Vol. 11, pp. 105-125.

[21] Finkelman, R.B., Bostick, N.H., Dulong, F.T., Senftle, F.E., Thorpe, A.N., 1998, “Influence of an Igneous Intrusion on the Inorganic Geochemistry of a Bituminous Coal from Pitkin County, Colorado.” International Journal of Coal Geology, Vol. 36, pp. 223-241.

[22] Goodarzi, F., Cameron, A.R., 1990, "Organic Petrology and Elemental Distribution in Thermally Altered Coals from Telkwa, British Columbia.” Energy Resources, Vol. 12, pp. 315-343.

[23] Merritt, R.D., 1985, “Thermal Alteration and Rank Variation of Coal in the Matanuska Field, South-Central Alaska.” International Journal of Coal Geology, Vol. 14, pp. 255-276.

[24] Querol, X., Alastuey, A., Lopez-Soler, A., Plana, F., Fernandez-Turiel, J.L., Zeng, R., Xu, W., Zhuang, X., Spiro, B., 1997, "Geological Controls on the Mineral Matter and Trace Elements of Coals from the Fuxin Basin, Liaoning Province, Northeast China.” International Journal of Coal Geology, Vol. 34, pp. 89-109.

[25] Querol, X., Alastuey, A., Zhuang, X., Hover, J.C., Lopez-Soler, A., Plana, F., Zeng, R., 2001, "Petrology, Mineralogy and Geochemistry of the Premian and Triassic Coals in Leping Area, Jiangsi Province, Southeast China.” International Journal of Coal Geology, Vol. 48, pp. 23-45.

[26] Alexandra, G.N., Paul, C.F., 2004, "Changes in Geochemistry and Mineralogy of Thermally Altered Coal, Upper Hunter Valley, Australia.” International Journal of Coal Geology, Vol. 57, pp. 197-210.

[27] Suchy, V., Frey, M., Wolf, M., 1997, “Vitrinite Reflectance and Shear Induced Graphitization in Orogenic belts: A case Study from the Kandersteg is, Helvetic Alps, Switzerland.” International journal of Coal Geology, Vol. 34, pp. 1-20.

[28] Bourrat, X., Oberlin, A., Escalier, J.C., 1986, "Microtexture and Structure of Semi-Cokes and Cokes.” Fuel, Vol. 65, pp. 1490-1500.

[29] Goodarzi, F., Murchison, D.G., 1977, "Effect of Prolonged Heating on the Optical Properties of Vitrinite.” Fuel, Vol. 56, pp. 80-96. 
[30] Munshi, P.L., 1995, "Experience of Dealing with Fires in Jharia Coal Field-Introduction of Diagnostic Technique.” National Seminar on Mine Fires, Varanasi, pp. 82-90.

[31] Banerjee, S.C., 1985, “Spontaneous Combustion of Coals and Mine Fires.” AA Balkerma, Rotterdam.

[32] Malhotra, K.K., Rai, P.N., 1989, "Land Subsidence Due to Fires and Measures Taken to Combat the Effects on Structures - A Case Study.” Proceedings: International Symposium on Land Subsidence, pp. 331-339.

[33] Singh, R., Singh, A.K., Mandal, P.K., 2002, "Cuttability of Coal Seams with Igneous Intrusions.” Engineering Geology, Vol. 67, pp. 127-137. 